\title{
Activity of Distamycin A on the Induction of Adaptive Enzymes in Escherichia coli
}

\author{
By AURORA SANFILIPPO, ENZA MORVILLO AND M. GHIONE \\ Farmitalia, Istituto Richerche di Base, Milano, Italy
}

(Received 12 October 1965)

\begin{abstract}
SUMMARY
We have studied the effect of distamycin $\mathbf{A}$ on the synthesis of inducible enzymes in Escherichia coli strain $\mathrm{k12}$. Distamycin A did not inhibit the growth of $E$. coli $\mathrm{K} 12$ when the micro-organism already contained constitutive or inducible enzymes for the metabolism of sugars. The growth of $E$. coli was prevented when distamycin A was present during the enzymic induction. Distamycin $\mathbf{A}$ inhibited the formation of inducible $\beta$-galactosidase; the activity of the antibiotic was directly related to its concentration, but independent of the concentration of the inducer. Thus it does not seem that distamycin A causes a decrease of the concentration of inducer. The enzyme synthesized in the presence of subinhibitory concentrations of distamycin A showed the same kinetic behaviour as $\beta$-galactosidase induced under normal conditions.
\end{abstract}

\section{INTRODUCTION}

Distamycin A is an antibiotic produced by Streptomyces distallicus isolated in our laboratories, the structure of which was identified and confirmed by total synthesis by Arcamone et al. (1964). Partially purified preparations of distamycin A exerted an inhibitory action on the development of experimental tumors (Di Marco et al. 1962). The purified crystalline antibiotic shows antiviral activity on vaccinia and herpes simplex viruses in vitro or in experimental infections (Casazza \& Ghione, 1964; Verini \& Ghione, 1964; Werner, Ganter \& de Ratuld, 1964). The antibiotic interferes with some phases of the multiplication of the phages $\mathrm{T} 1$ and $\mathrm{T} 2$ of Escherichia coli (Di Marco et al. $1963 a, b$ ). On the basis of the hypothesis that distamycin A blocks some enzymic processes induced by the phages, we investigated the action of the antibiotic on the induction of adaptive enzymes in $\boldsymbol{E}$. coli. For this purpose we studied the activity of distamycin $\mathbf{A}$ on bacterial growth which depended on the induced synthesis of carbohydrate-metabolizing enzymes, and the action of the antibiotic on the induction of $\beta$-galactosidase.

\section{METHODS}

The strain Escherichia coli $\mathbf{k} 12$ used was grown in a complex medium (peptone broth, nutrient broth, yeast extract broth) or in a chemically defined medium, namely, Davis salt solution (Davis \& Mingioli, 1950) supplemented with carbohydrates which were metabolizable by constitutive enzymes (carbohydrates of type I) or by inducible enzymes (carbohydrates of type II) of $E$. coli. Carbohydrates of type $I$, besides the glucose of the original medium of Davis \& Mingioli, are mannose, 
fructose; carbohydrates of type II are lactose, trehalose, ribose, arabinose, xylose. The bacteria were previously washed in Davis salt solution and incubated at $37^{\circ}$ for $2-3 \mathrm{hr}$ in order to obtain metabolic starvation.

The inoculum was standardized at $10^{6}$ organisms $/ \mathrm{ml}$; the bacterial growth was measured by a photometric method (Beckman spectrophotometer at wavelength $600 \mathrm{~m} \mu$ ), by the use of a calibration curve. For $\beta$-galactosidase induction Escherichia coli $\mathrm{K} 12$ was incubated in peptone broth (peptone, $2 \%$ ) containing $0.5 \%$ lactose. Assays for $\beta$-galactosidase were made by the colorimetric procedure of Lederberg (1950) with washed organisms resuspended in $0.02 \mathrm{M}-\mathrm{Na}$ phosphate buffer $(\mathrm{pH} \mathrm{7.5)}$ to a constant extinction value $(0 \cdot 200$, at $600 \mathrm{~m} \mu)$. The organisms were incubated at $25^{\circ}$ with the addition of $o$-nitrophenyl- $\beta$-galactoside (ONPG) $0.0005 \mathrm{M}$. The reaction was stopped by adding $\mathrm{Na}$ carbonate to $0 \cdot 2 \mathrm{M}$ final concentration. The concentrations of the released $o$-nitrophenol (ONP) were determined photometrically (Beckman spectrophotometer, at $420 \mathrm{~m} \mu$ ) and represented a measure of the activity of the enzyme.

\section{RESULTS}

\section{Activity of distamycin A on growing cultures of Escherichia coli $\mathrm{K} 12$}

Distamycin A even at relatively high concentrations (50 $\mu \mathrm{g} . / \mathrm{ml}$.) did not modify the growth of $E$. coli $\mathrm{x} 12$ in complete media or in defined media containing as sole carbon source carbohydrates which are metabolized by constitutive enzymes of $E$. coli. On the other hand, distamycin A showed a marked inhibitory action when the bacterial growth depended upon a de novo synthesis of induced enzyme, as in the case of the utilization of pentoses or disaccharides by the wild-type strain (Table 1).

Table 1. Growth of Escherichia coli $\mathrm{K} 12$ in presence of distamycin $\boldsymbol{A}$ $20 \mu \mathrm{g} . / \mathrm{ml}$. after incubation for $36 \mathrm{hr}$ at $37^{\circ}$

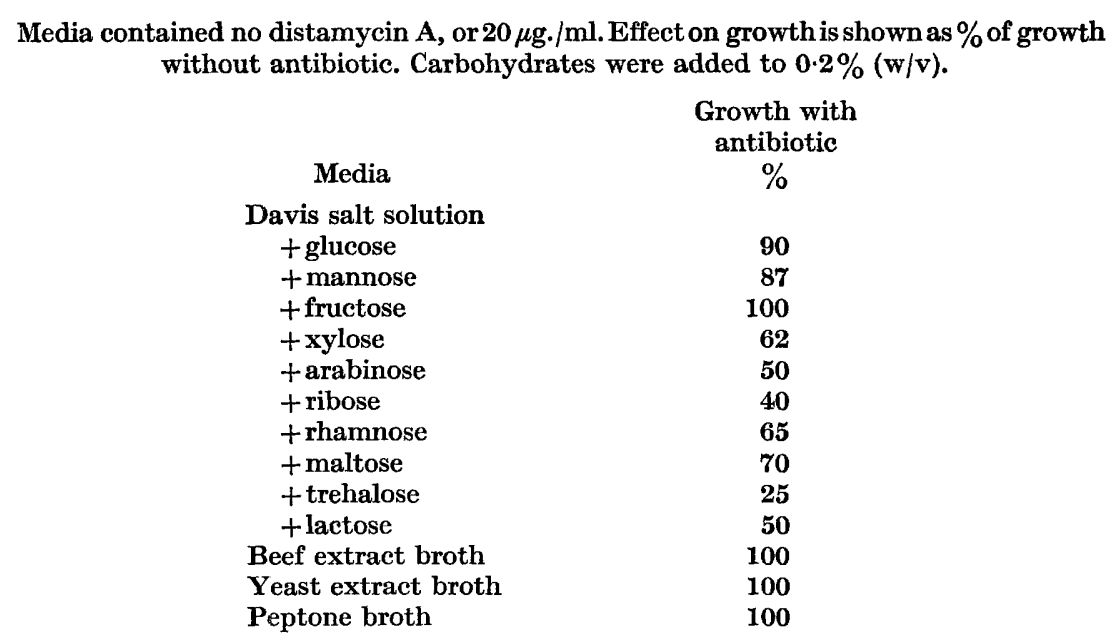

Distamycin A showed no inhibitory effect on the development of a strain of $E$. coli $\mathrm{x} 12$ which was previously adapted to metabolize the pentoses or disaccharides (Table 2).

At least in the case of arabinose, distamycin A did not act as an antimetabolite 
(Woolley, 1952); even high concentrations of arabinose $(0 \cdot 8 \%$, inhibitory per se) did not antagonize the action of distamycin A (Table 3 ).

The inhibitory action of distamycin A was also shown with strains already adapted to utilize substrated different from those actually present in the medium (Table 4).

Table 2. Growth of induced and non-induced Escherichia coli $\mathrm{K} 12$ strains in presence of distamycin $A\left(20 \mu \mathrm{g} . / \mathrm{ml}\right.$.) and of various carbohydrates $\left(0.2^{\circ} \%\right)$ in Davis salt solution (DSS)

\begin{tabular}{|c|c|c|}
\hline $\begin{array}{l}\text { Maintenance } \\
\text { media }\end{array}$ & $\begin{array}{l}\text { Assay } \\
\text { media }\end{array}$ & $\begin{array}{c}\text { Growth with } \\
\text { distamycin } A \text { as } \\
\% \text { of growth } \\
\text { without antibiotic }\end{array}$ \\
\hline $\begin{array}{l}\text { Peptone broth } \\
\text { DSS + arabinose }\end{array}$ & DSS + arabinose & $\begin{array}{r}50 \\
100\end{array}$ \\
\hline $\begin{array}{l}\text { Peptone broth } \\
\text { DSS + xylose }\end{array}$ & DSS + xylose & $\begin{array}{r}50 \\
110\end{array}$ \\
\hline $\begin{array}{l}\text { Peptone broth } \\
\text { DSS + rhamnose }\end{array}$ & DSS + rhamnose & $\begin{array}{r}65 \\
105\end{array}$ \\
\hline $\begin{array}{l}\text { Peptone broth } \\
\text { DSS + trehalose }\end{array}$ & DSS + trehalose & $\begin{array}{r}26 \\
108\end{array}$ \\
\hline $\begin{array}{l}\text { Peptone broth } \\
\text { DSS + maltose }\end{array}$ & DSS + maltose & $\begin{array}{r}63 \\
106\end{array}$ \\
\hline
\end{tabular}

Table 3. Growth of Escherichia coli $\mathrm{K} 12$ (strain routinely maintained in peptone agar) in Davis salt solution with the addition of arabinose and distamycin $A$

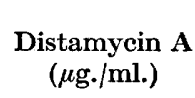

$\begin{array}{rr}80 & \\ 40 & \\ 20 & 5 \\ 10 & 12 \\ 0 & 17\end{array}$

ID $50 \dagger$

$(\mu \mathrm{g} . / \mathrm{ml}$.

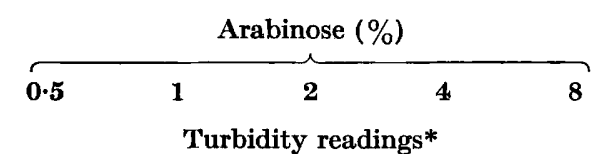

Turbidity readings*

$\begin{array}{rrrrr}\mathbf{0} & 0 & 0 & 0 & 0 \\ 0 & 0 & 0 & 0 & 0 \\ \mathbf{5 7} & \mathbf{2 9} & 43 & 65 & 0 \\ 123 & 123 & 110 & 76 & 64 \\ 173 & 185 & 154 & 140 & 121 \\ 15 & 12 & 15 & 10 & 10\end{array}$

* Turbidity readings at $600 \mathrm{~m} \mu$. † Values of median inhibitory dose (ID 50).

Table 4. Growth of lactose-adapted or unadapted strains of Escherichia coli $\mathrm{K} 12$ in presence of distamycin $A(20 \mu \mathrm{g} . / \mathrm{ml}$.$) and various carbohydrates (0.2 \%)$ in Davis salt solution (DSS)

\begin{tabular}{|c|c|c|}
\hline & & $\begin{array}{l}\text { Growth with } \\
\text { distamycin A as }\end{array}$ \\
\hline $\begin{array}{l}\text { Maintenance } \\
\text { media }\end{array}$ & $\begin{array}{l}\text { Assay } \\
\text { media }\end{array}$ & $\begin{array}{l}\% \text { of growth } \\
\text { without antibiotic }\end{array}$ \\
\hline
\end{tabular}

Peptone broth

DSS+lactose

\} DSS + arabinose \{

55

Peptone broth

DSS + lactose

\} DSS + trehalose

60

Peptone broth

DSS + lactose
\} DSS + lactose \{

\section{(1)}

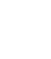


The viability of the bacteria was not affected by distamycin $A$; the growth of the organisms was restored when the medium containing distamycin A was supplemented with glucose (Table 5).

Table 5. Growth of Escherichia coli $\mathrm{K} 12$ (strain routinely maintained in peptone agar) in presence of distamycin $A$ (20 $\mu \mathrm{g} . / \mathrm{ml}$.) in Davis salt solution with arabinose (culture $A$ ) or with further addition of glucose after incubation for $18 \mathrm{hr}$ (culture B)

\begin{tabular}{cccc} 
Culture & \multicolumn{3}{c}{ Incubation time (hr) } \\
\cline { 2 - 3 } & 0 & 18 & 36 \\
Relative & turbidity readings* \\
B & 0 & 45 & 45 \\
& 0 & 45 & 215
\end{tabular}

* Relative turbidity readings at $600 \mathrm{~m} \mu$.

\section{Activity of distamycin $\boldsymbol{A}$ on the $\beta$-galactosidase induction}

Distamycin A up to $100 \mu \mathrm{g} . / \mathrm{ml}$. did not affect the activity of $\beta$-galactosidase, the rate of ONP formation over $18 \mathrm{~min}$. was the same in presence or absence of the antibiotic, but it did interfere with the induction of this enzyme. The action of distamycin A was proportional to its concentration (Fig. 1) and independent of the concentration of inducer within the concentrations tested (Fig. 2). The effect of distamycin A was clearly evident when it was added to the medium together with inducer, or not mere than $30 \mathrm{~min}$. later; when added after $30 \mathrm{~min}$. the activity rapidly decreased (Fig. 3).

The $\beta$-galactosidase enzymes induced either in the presence of subinhibitory concentrations of distamycin $\mathbf{A}$ or in its absence showed the same kinetic characteristics. The value of the Michaelis constant $(\mathrm{Km})$ calculated according to the procedure of Lineweaver-Burk (1934) was $2.16 \times 10^{-4} \mathrm{M}$ for the enzyme induced in a medium free from antibiotic and $2.26 \times 10^{-4} \mathrm{M}$ for the enzyme induced in the presence of distamycin A.

\section{DISCUSSION}

Our results support the hypothesis of an interference of distamycin A with the mechanisms involved in the induction of adaptive enzymes. The reported data show that the growth of Escherichia coli $\mathrm{K} 12$ was prevented by distamycin A only when the multiplication of the micro-organisms depended on the formation of an induced enzyme required for the metabolism of a carbohydrate present in the medium as sole carbon source. The growth of $E$. coli was inhibited when the antibiotic was present during induction of the enzyme. These characteristics of the action of distamycin A suggest that it does not inhibit the metabolic processes catalized by enzymes (either constitutive or inducible) already present in the organisms, but interferes with the system involved in the enzymic induction. In the light of these findings it seems hazardous to draw any conclusion on the specific site of action of distamycin $\mathbf{A}$ in such a complex mechanism as enzymic induction and repression (Monod \& Cohn, 1952; Jacob et al. 1960; Jacob \& Monod, 1961). On the basis of the present results the site of action of distamycin $A$ has to be common to 
several pathways since different enzymic adaptive systems are blocked by this antibiotic. The investigation of the distamycin A activity on the induction patterns of some other enzymes (such as penicillinase in Bacillus subtilis and serine or threonine deaminase in Escherichia coli $\mathrm{k}$ 12) are hindered by the interference displayed by the antibiotic on the assay methods. We cannot deduce from our data

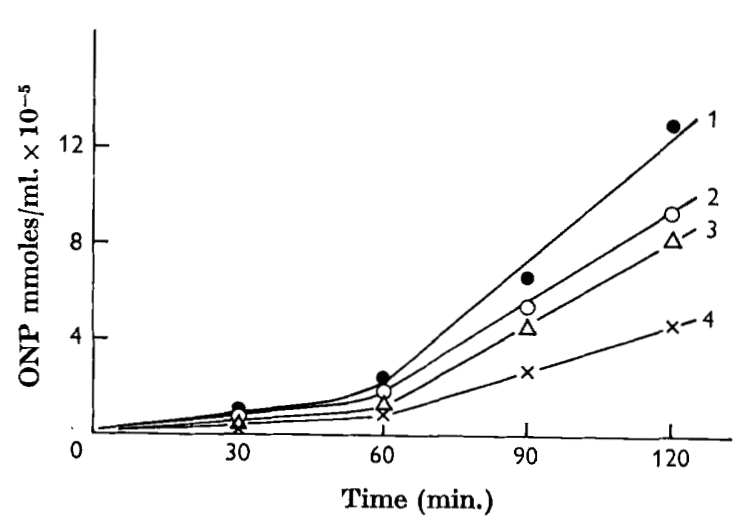

Fig. 1

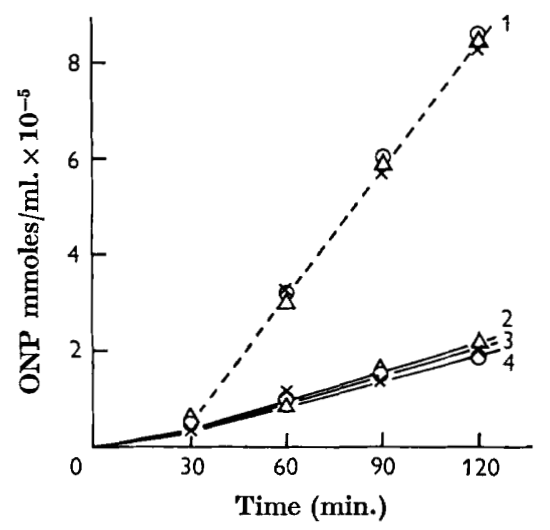

Fig. 2

Fig. 1. Activity of distamycin A on the induction of $\beta$-galactosidase in Escherichia coli $\mathbf{k} 12$. The incubation time in presence of the inducer is plotted against the concentrations of ONP released. Curve 1, control; curve 2, distamycin A $20 \mu \mathrm{g} . / \mathrm{ml}$.; curve 3, distamycin A $40 \mu \mathrm{g} . / \mathrm{ml}$.; curve 4, distamycin A $80 \mu \mathrm{g} . / \mathrm{ml}$.

Fig. 2. Activity of distamycin A $(100 \mu \mathrm{g} . / \mathrm{ml}$.) on the induction of $\beta$-galactosidase in Escherichia coli $\mathrm{K} 12$ in presence of various concentrations of inducer. The incubation time in presence of the inducer is plotted against the concentrations of ONP released. Curve 1, lactose 0.1-0.5-2.5\%; curve 2, lactose 0.1 \% + distamycin A; curve 3, lactose $0.5 \%+$ distamycin A; curve 4, lactose $2.5 \%+$ distamycin $\mathbf{A}$.

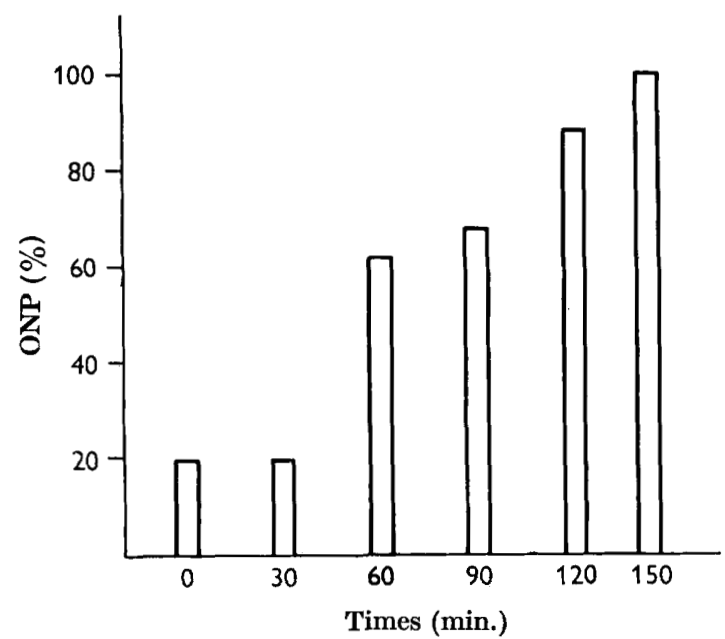

Fig. 3. $\beta$-Galactosidase activity of cultures of Escherichia coli $\mathrm{K} 12$ to which the distamycin $A$ was added at various intervals during the adaptation period. On the axis of abscissa the times between the addition of the inducer and that of the antibiotic. On the axis of ordinate $\%$ of ONP released (activity of untreated culture $=100$ ). 
if distamycin $\mathbf{A}$ inhibits the induction of permeases and/or kinases. The work is still in progress, and Barr's (1963) considerations on the danger of extreme theorization lead us to continue on the experimental rather than on the merely theoretical basis.

\section{REFERENCES}

Arcamone, F., Penco, S., Nicolella, V., Orezzi, P. \& Pirelli, M. A. (1964). The structure and synthesis of distamycin A. Nature, Lond. 203, 1064.

Barr, H. J. (1963). A new genetical particle: the hypotheson. J. theoret. Biol. 3, 514.

Casazza, A. M. \& GHione, M. (1964). Therapeutic action of distamycin A on vaccinia virus infections in vivo. Chemotherapia, 9, 80.

Davis, B. D. \& Mingroli, E. S. (1950). Mutants of E. coli requiring methionine or vitamin B 12. J. Bact. 60, 17.

Di Marco, A., Gastani, M., Orezzi, P., Scotti, T. \& Arcamone, F. (1962). Experimental studies on distamycin A. A new antibiotic with cytotoxic activity. Cancer Chemoth. Rep. $18,16$.

Di Marco, A., Ghione, M., Sanfilippo A. \& Morvillo, E. (1963a). Selective inhibition of the multiplication of phage T1 in $E$. coli $\mathrm{k12}$. Experientia, 19, 134.

Di Marco, A., Ghione, M., Migliacci, A., Morvillo, E. \& Sanfilippo, A. (1963b). Studi sul meccanismo dell'azione antifagica dell'antibiotico distamicina A. G. Microbiol. $11,87$.

JACOB, F. \& Monon, J. (1961). Genetic regulatory mechanisms in the synthesis of protein. J. mol. Biol. 3, 318.

Jacob, F., Perrin, D., Sanches, C. \& Monod, J. (1960). L'opèron: groupe de gènes à expression coordonnèe par un opérateur. C. r. hebd. Séanc. Acad. Sci., Paris, 250, 1227.

LEDERBERG, J. (1950). The $\beta$-D-galactosidase of $E$. coli strain к 12. J. Bact. 60, 381.

Lineweaver, H. \& Burk, D. (1934). The determination of enzymes dissociation constants. J. Am. chem. Soc. 56, 658.

Monod, J. \& CoHn, M. (1952). La biosynthèse induite des enzymes. Advanc. Enzym. 13, 62.

Verini, M. A. \& Ghione, M. (1964). Activity of distamycin A on cell cultures infected with vaccinia virus. Chemotherapia, $9,144$.

Werner, G. H., Ganter, P. \& DE Ratuld, Y. (1964). Studies on the antiviral activity of distamycin A. Chemotherapia, 9, 65.

Woolley, D. W. (1952). A Study on Metabolites. New York: J. Wiley and Sons. 